\title{
The Influence of Industrial Air Pollution Forest Lichens at Tomaszow Mazowiecki Region (Central Poland)
}

\author{
KRYSTYNA CZYZEWSKA \\ Department of Geobotany and Conservation, Kodz University, Banacha 12/16. \\ 90.237 Łodź. Poland
}

C z y z e w 8 k a K: The influeace of Industrial Air Pollution on Forest Lichens at Tomaszów Mazowiceki Region (Central Poland). Acta Mycol. XXV11 (2): 247-256, 1991-1992.

The influence of mixed gases pollution ( $\mathrm{SO}_{2}, \mathrm{H}_{2} \mathrm{~S}$ and $\mathrm{CS}_{2}$ ) on epiphytic and epixylic lichens growing on Pinus syjvestris in the aature conditions is the matter of consideration. In the case of some lichens, c.g. Iecanord conizacoides, Scoliciosporum clalorococcum and Thelocarpon laurcri the toxitolerant to the air pollution is proved by the authoress.

\section{INTRODUCTION}

The gasous $\mathrm{SO}_{2}, \mathrm{H}_{2} \mathrm{~S}$ and $\mathrm{CS}_{2}$ emitted into the air by the Tomaszow Factory of Man-Made Fibres "WISTOM" (TZWS) in Tomaszów Mazowiecki (Central Poland) were considered a factor limiting the growth of epiphytic lichens occurring on Pinus sylvestris in the forests surrounding the factory. It was expected that the picture of the effects and a range of spatial influence of TZWS emission on these forests would be obtained. The question of an influence of industry air pollution on forest vegetation is included within the problems of plant cover synanthropization and phytotoxic gases can be regarded as a synanthropization factor of an indirect character, resulting from the links between biocoenose and biotope ( $\mathrm{F} \mathrm{a} \mathrm{i}$ í $\mathrm{s} \mathrm{k}$, 1972). If we take epiphytic lichens as biological indices of air pollution, we should assume that:

- an occurrence of epiphytic lichens is a constant feature of a given biocoenoses both in time and in spatial meaning,

- as inherent components of forest biocoenose lichens should be subjects to all the laws and principles governing its behaviour,

- if air pollution cxerts a harmful influence on living biocoenoses components it must have the similar influence on the lichens, which on the species level should be 
reflected in the changes of the number of species, their spatial distribution, their quantitativeness, etc.,

- the frequency of the occurrence of lichens, their species variety and abundance should depend not only on anthropogenic factors but also on natural ones, interacting in a complex way,

- when being shaped by the natural complex of biotic and abiotic factors the lichen distribution should be of rather mosaic and more or less even character, while being formed under the strong influence of air pollution it should exhibit zonal features ( $S$ w i b od a and $K$ a le m b a, 1978 and the literature quoted there),

- to examine the influence of air pollution on lichens all other environmental factors which might influence their species variety and distribution had to be neglected.

\section{THE OBJECT- OF INVESTIGATIONS}

Tomaszów Mazowiecki is an industrial town of an average size (aboul 60000 inhabitants) emitting into the air gases and dusts from 10 larger and a few smaller factories. According to the data from the period 1974-1977 the mean gas emission cquals $\mathrm{SO}_{2}-1243 \mathrm{~kg} / \mathrm{h}, \mathrm{CS}_{2}-571 \mathrm{~kg} / \mathrm{h}, \mathrm{H}_{2} \mathrm{~S}-97 \mathrm{~kg} / \mathrm{h}$ and the mean dust emission amounts to $961 \mathrm{~kg} / \mathrm{h}$. Over $90 \%$ of $\mathrm{SO}_{2}$ emission is sent out into the air by Factory "WISTOM" which produces viscose fibres. The gasous $\mathrm{H}_{2} \mathrm{~S}$ and $\mathrm{CS}_{2}$ are characteristic of this factory (O l a c z e k, U r b a n e k, 1978).

The town itself is situated in the margin area of the Łod $z$ Upland sloping down distinctly in an eastward direction. This fact logether with SW-NE-W-E configuration of the Pilica River valley enable the west winds to blow frecly towards Inowlodz. These winds mainly carry air pollutants from TZWS which is located in the N-E suburbs of the town.

An important feature of the local climate is the dominance of the west winds $(23 \%)$, light winds, from $2-5 \mathrm{~m} / \mathrm{sec}(79 \%)$ and of calms $(13 \%)$. Outside the Pilica valley winds from all the directions are reduced by $40-70 \%$ and with low wind velocity even by $100 \%$ on an average. The poor ventilation of this area logether with the wide range of temperature inversion in the Pilica valley ate not favourable to a spontaneous purification of air both in the town and in the forests $(\mathrm{Z} \mathrm{c} \mathrm{h}, \mathrm{Z}$ a w adzka, 1960; Tarajkowska, Zawadzka, 1963; Rydzak, Krysiak, 1970).

A vast forest area expands to the east of the factory in the blowing zone of prevailing winds. It occupies the Pilica valley of the west-east rivercourse and the high plain adjoining the valley. Varied relief and habitat differentiation are typical of the high plain running across $(\mathrm{N}-\mathrm{S})$ the river valley.

Both in primary and natural plant cover of the Tomaszow Region deciduous 
forests: light oak forest and oak and hombeam forests, prevailed over pine forests (O l a c zek, Ja kubowska - G a bar a, 1978). At present, various development phases of pine monoculture in habitats of deciduous and pine forests dominate due to complete clearing and afforestation with Pinus sylvestris, which have been carried out since the 19 th century. Here, in the large and well preserved area of forests with the first gencration of Pinus sylvestris the regeneration process of deciduous forests is clearly seen.

\section{MATERIAL AND INVESTIGATION METHODS}

Epiphytic lichens groving on Pinus sylvestris were investigated in the years 1976-1980. These trees are distributed uniformly within the said forests. It was assumed that the initial results would be considered globally for the whole period of the factory activity (starting from 1911), that is during all the time of the existence of the examined tree generation (O l a c z c k, U r ba n e k, 1978).

Two age groups of trees were taken into consideration, namely: (50)-70-100 and over 100 years of age. Field experiences show that in natural conditions on the trees of the two age groups a constsnt population of lichens characteristic of physically mature individuals of the particular tree has already been formed.

When the investigated localities were being chosen their homogenity was taken into account, namely only the epiphytes from the inside of forest divisions with a similar microclimate were recorded, the trees groving near division and forest roads being excluded. The data from one locality (point) are the sum of lichen appearance on at least 10 trees. The mean coverage of trunks by lichens was roughly estimated and expressed in percentage numbers (Table 1).

The following investigation methods were used:

1. Hajduk's method (Ś w i boda, 1970), i.e. the method of transects on chosen directions of wind rose. A concentration of emission sources in TZWS was assumed to be the zero point. The transect points gradually moving away from the emission sources were distributed at 200 meters' distances within the range of $1 \mathrm{~km}$ and farther at 500 - meters' distances.

2. Cartographic methods. Maps of species distribution-to obtain them the tree-stand 1:20000 map (Figs 1,2) was covered with a grid. The basic area is a $500 \times 500 \mathrm{~m}$ square. Each square contains information on the existence or non existence of the investigated species as well as the mean cover degree of tree trunks by the species according to the six-degree scale (Fig. 1). The method of Ashby and Pidgeon's isonomes ( $\mathrm{Ke} \mathrm{r} \mathrm{s} \mathrm{h} \mathrm{a} \mathrm{w,} \mathrm{1978)} \mathrm{was} \mathrm{used} \mathrm{in} \mathrm{order} \mathrm{to} \mathrm{illustrate} \mathrm{the} \mathrm{change-}$ ability on spatial distribution of epiphytic species within the whole investigated area. A network of forest divisions was used in this method. 


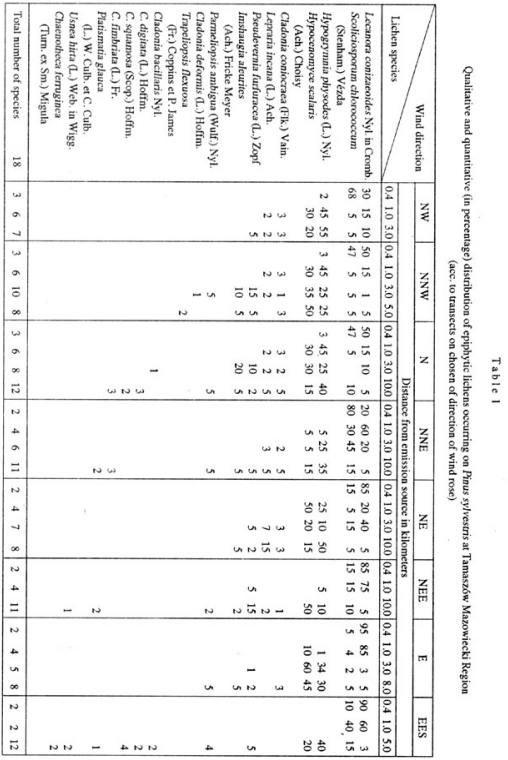




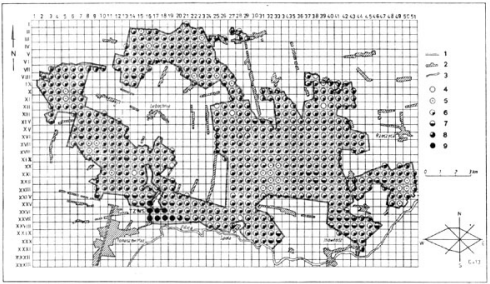

Fig. 1. Distribution of Lecanora conizacoides oa Pinus sylvestris at the forests of Tomaszów Mazoxiecki Region

1 - lintils of the ferest; 2 - places; 3 - rivers: 4 - lacking species: 5 - species cover up to $5 \%$ of sample oa the tree-irunk: 6 - from 5 to $25 \% ; 7$ - from 25 to $50 \% ; 8$-from 50 to $75 \% ; 9$ - from 75 to 100 o; TZWS - Tomasz $5 w$ Faetory on

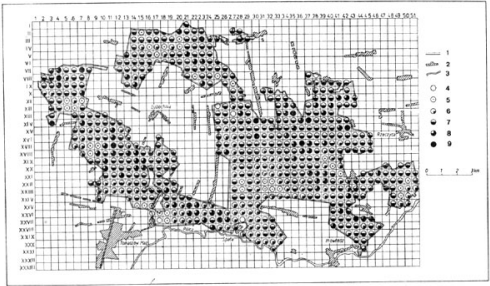

Fig. 2. Distribution of Hypogymina physodes on Pinus sylvestris at the forests of Tamaszow Mazowiecki 


\section{RESULTS OF INVESTIGATIONS}

Altogether 18 lichen species grow on Pinus sylvestris: 12 of them are typical epiphytes and the remaining ones nonspecific (facultative species), i.e. epigaeic lichens which have found their secondary habitats on tree bark. The spatial distribution of epiphytic lichens shows their quality and quantity changes connected with the gradient of the distance from emission sources and with the direction of prevailing winds (Tab. 1; Figs 1, 2, 3).

Within the distance of $1 \mathrm{~km}$ from the emission sources only two species occur, namely: Lecanora conizaeoides and Scoliciosporum chlorococcum. They form a distinctly limited zone extending towards the blowing direction of the prevailing winds (Tab. 1; Fig. 1). This zone accumulates $25.2 \%$ of all the air pollution emitted by the factory.

Within the space of $800 \mathrm{~m}$ or $1 \mathrm{~km}$ up to $3-4 \mathrm{~km}$ other species appear. These are Hypogymnia physodes (at the base of trunks, on their lee side) and a bit farther Hypocenomyce scalaris, Lepraria incana, Cladonia coniocraea. This area accumulates $19.5 \%$ of all the air pollution emitted by the factory.

Within the range of over $3-4 \mathrm{~km}$ Pseudevernia furfuracea, Imshaugia aleurites and the species of narrover ecological amplitude begin to appear. This zone accumulates $16 \%$ of all the pollution cmilted by the factory.

The following quantitative picture of the occurrence of epiphytes was obtained.

In the area closest and close to the emission sources the aboundance of Lecanora conizacoides (Tab. 1), not occurring any farther from the emission sources, can be observed. Its individuals often yield fruit bodies and have characteristic thick thallus which breaks into soredia. As the distance from the emission sources increases thallus loses this feature and diminishes its quantitativeness (Fig. 1). Scoliciosporum chlorococcum is found close to the emission sources but loses its ability to produce fruit bodies. Most likely the weakening of symbiotic links between fungous and alga components takes place, which might be worth investigating more thoroughly. In farther parts of the forest Scoliciosporum chlorococcum regains its ability to produce fruit bodies but simultaneously decreases in number. In Polish natural conditions both species are characteristic of initial development stages of epiphytic communities as well as of young and physically immature trees.

Hypogymnia physodes exist in two distinct varieties: as var, subcrustacea when closer to the emission sources and as var. physodes farther away. Some other varicties are also observed. Generally it appears more abundantly on young trees. The distribution of this taxon is presented in Fig. 2.

If we take a look at the spatial distribution of the numbers of lichen species (Fig. 3) we shall see that the changes are rather continuous and not step-wise and that they permit explicit determination of the areas being affected by the emission to various degrees, maybe except for the zone closest to the emission sources. The 
changes of a progressive character are better seen in the area extending $6-8 \mathrm{~km}$ towards the east and south-east and $2 \mathrm{~km}$ towards the north-east and north from the emission sources. A remarkably mosaic-like arrangement in the spatial distribution of the numbers of lichen species is typical of other areas.

I would like to call your attention to the spatial distribution of a liny epixylic species Thelocarpon laureri (Fig. 4). It grows on pine stumps at the initial stages of their docomposition. A great accumulation of localities of this lichen occurs close to the emission sources and up to $10 \mathrm{~km}$ along the margin area of the Pilica valley, i.c. in the zone of the most intensive eastward translocation of the air pollution.

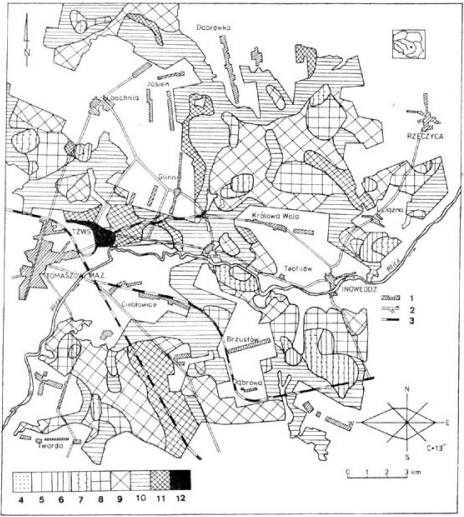

Fig, 3, Isonomes of occurrence frequency of lichens on Pinus sylvestris

1 -places; 2 -roads; 3 -railways; 4 - from 20 to 21 taxa; 5 -from 17 to 19 taxa; 6 - from 15 to 16 taxa; 7 -from 12 to 14 เала; 8 - from 10 to 11 taxa; 9 - from 8 to 9 taxa; 10 - from 5 to 7 taxa; 11 - from 3 to 4 taxa; 12 - from 1 to 2 taxa; 


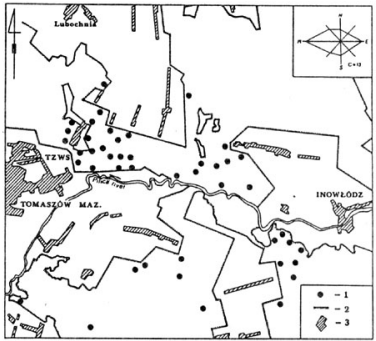

Fig. 4. Distribution of Thelocarpon Iaureri, on epixylic lichen 1 - localities of Thelocarpon laurert, 2 - liniss of the forest; 3 -places; TZWS - Tomaszów Factory oa Man-Made Fibres "WISTOM"

\section{CONCLUSIONS}

The emission of viscose fibre industry exerts harmful influence on epiphytic lichens of the forests surrounding Tomaszow Mazowiecki. These damages, however, are caused by $\mathrm{SO}_{2}$ and not by the gases typical of this industry.

The neighbourhood closest to the emission sources lacks a lichen desert which is characteristic of industrial towns ( $\mathrm{L}$ a u n d o n, 1973 et al.).

Proportionally to the intensity of the air pollution there appear the phenomena of the simplification of a species composition and of the degression of a species number.

The more closely to the emission sources the phytocoenoses of epiphytic lichens are located, the more explicitly they exhibit the features of the communities being primitive or characteristic of the initial devolopment stages in the succession process, i.e. their quantitative increase and decrease in quality are observed.

The vividness of the picture of epiphytes' distribution is blurred by the synergistic 
effects of the air pollution, of the conditions of habitats and forest vegetation (natural vegetation, influence of forest economy - degeneration forms: pinetization, strong fruticetization, i.e. rich population of shrubs).

The following three species of lichens are distinctly toxitolerant in the investigated area: Lecanora conizaeoides, Scoliciosporum chlorococcum and Thelocarpon laureri. Their resistance to the air pollution of industrial origin has already been confirmed when the problem of the influence of $\mathrm{SO}_{2}$ on lichens was investigated (i.e. Hawksworth etal., 1973; Pisút, Jelinková, 1971; Ahti, Vitikainen, 1974; Coppins, 1976; Czyżewska, 1988 (1989); Ciesliński, C z y ż e w sk a, 1989; Lisk a, P is út, 1989, and others).

\section{REFERENCES}

A h ti T, Vitika in en O., 1974. Bacidia chlorococca a common toxitolerant lichen in Finland. Mem. Soc. Fauna Flora Fenn. 49: 95-100.

Cieslin ski S., Czyzewsk a K. 1989. The threat to lichens in Poland and their conservation. [In]: 19th Intern. Phytogeogr. Exc. 1989, July 7-26. "Flora and Vegetation of Poland Changes, Management and Conservation: 1928-1988", 1.28 Krakow:

Czy z e w s ka K., 1988 (1989). Changes in the lichen flora influenced by the Belchatów Industrial Region. Acta Mycol. XXIV: $93-100$.

Coppi in B. J., 1976. Distribution patterns shown by epiphytic lichens in the British Isles. [In]: Brown D.H., Hawkswoeth D. L., Bailey R. H. (eds), Lichenology; Progress and Problems: 249-278. Academic Press, London-New York

Fa li 6 s ki J. B., 1972. Sy nantropizacja szaty roślinnej-pcóba okreslenia istoty procesu i głównych kienunków badań. Phytocoenosis, 13: 157-170.

Hawksworth D.L., Rose F. Coppin s B.J.. 1973. Changes in the lichen flora of England and Wales Attributable to pollution of the air by sulphur dioxide. [In] Ferry B. W. et al. (eds), Air pollution and lichens: 330-367. Athlone Press, London.

Kersh aw K. A.. 1978. Ilościowa i dynamiczna ekologia rólin. PWN, Warzzawa: 1-383.

L au nd on J.R., 1973. Urban lichens studies. [In]: Ferry B. W, et al. (eds), Air pollution and lichens: 109-123 Athlone Press. Loadon.

L is k a J. P is ú t I. 1989. An example of bioindication on a large scale: mapping of lichens in Czechoslovakia. [In]: Bohác J., Rủzicka V. (eds), Hoc. Vth Int. Conf. Bioindicatores Deteriorisationis Regionis. Inst. of Landscape Ecology CAS: 81-86, Čske Budéjovice.

Olaczek R, J a kubows ka-Gabara J., 1978. Zespoly leśne dorzecza Pílicy. Studia Ośr. Dok. Fizjogr. PAN, 6: 145-164.

Olaczek R. Urbanek H., 1978. Complex method of studying the viscose fibre industry enission effects on vegetation. Env/Sem. 9 - Chem/Sem. 7/Com. 14: 1-11.

Pis út I. J el i n kova E., 1971. Ober die Artberechtigung der Flechte Lecanora conizacoides Nyl. ex Cromb. Preslia 43: 254-257

Rydzak J, Kry si a k K. 1970. Lichen flora of Tomaszów Mazowiecki. Vegetatio 21 (4-6): 375-397.

$\mathrm{S}$ w i e boda M., 1970. Wplyw przemyslowych zanieczyszczeń powietrza na roślinnosc w otoczeniu Fabry ki Supertomasyny „Bonarka" w Krakowie. Ochr. Przyr. 35: 161-220.

$\$$ w i e boda M. Ka le m ba A. 1978. Porosty biologicznym wskaźnikiem zanieczyszczenia powietrza atmosferycenego. Wiad. Ekol. 24 (3): 209-224.

Tarajkowska M. Zawadzka A, Zych S, 1963, Czy Spala moze byćcuzdroxiskiem? Wiad. Uzdrowiskowe 1-2:69-74.

Zaw a d $2 \mathrm{ka}$ A. Z Z ch S., 1960 .Zagadnienie wplywu órodków przemystu chenicznego a bioklimat niast na przykladzie Tomaszowa Maz. i Zgierza. Wiad. Uzdrowiskowe 1-2: 122-133. 